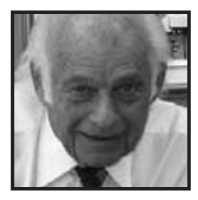

\title{
Curiosity, Passion and Learning
}

\author{
Avrum Morrow
}

\section{ABSTRACT}

In this commentary, business man and philanthropist Avrum Morrow maintains that learning need not be dull. He recalls some of the passionate teachers, from primary school to university, who had a profound influence on him. Through innovative art projects and singing arias in class to attention-grabbing science demonstrations, these teachers sparked his interest in art, music and science. He believes that curiosity and a receptive mind are the keys to lifelong learning.

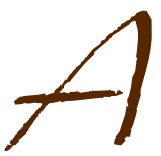

s far as I can recall, I was more interested in sports as a student than I was in my classes. I owe whatever knowledge I have to books that I have read, to friends who have sharpened my thinking, and to teachers who developed my critical faculties. If you are curious and receptive you can't help but learn. But I don't know where ideas come from. The creativity of the human mind has always amazed me. It seems to me that it is an accumulation of the books you have read, the people you have met who have influenced you, and the stories that have been told to you. You read something, you experience something, you imagine something, you put it all together and an idea is born. But the mind has to be shocked, seduced or otherwise provoked into action. Even the Biblical prophets understood that.

I suppose The Bible is as good an introduction to learning as any. The philosopher and poet, Max Eastman, taught me how to read The Bible, not as a work of theology or as the inspired work of God, but for pleasure and instruction. Max was a rebel, but a wonderful human being who was against the Second World War. He defended his position when he was tried as a dissident in a court of law. 
What I learned from him is that you can appreciate Scripture as an introduction to the human condition. You don't have to be a believer to realize that The Bible, like the works of Shakespeare, is an instructive primer into literature, the social sciences, ethics, history and psychology. All human virtues and transgressions are depicted in the Old and New Testaments-greed, charity, rape, incest. In its books you will find both loving and dysfunctional families, liars, cheats, honest men and murderers. The Bible never arrives at the ultimate definition of good or evil, but teaches that they are a paradox of opposites and introduces readers to the whole range of human experience. By reading scripture you venture into what Robert Browning (1855) calls "the dangerous edge of things," where you discover the contradictions of the human condition-"the honest thief, the tender murderer, the superstitious atheist" (p. 236).

Esther Tammarin was one teacher who made an impact on me when I was at Fairmont Elementary School, and who, upon reflection, stimulated my lifelong interest in art. She was original in her approach to teaching and had us do projects that were not part of the standard curriculum. For example, she had us make our own stained-glass windows by oiling brown wrapping paper and then having us cut window frames out of black construction paper. By pasting the oiled wrapping paper behind the cut-outs, the paper became translucent. I found it a pleasure to make windows out of oiled paper. The exercise almost certainly triggered my interest in art. Not only did I try my hand at painting, which I still do, but in 1965 our company commissioned an artist, R.D. Wilson, to draw Avmor's head office on Ste. Helen Street in Old Montreal for a Christmas card. His work became the first in what has become the Avmor Collection. Over the years various artists have painted portraits of the same building, and today more than 400 works by some of the country's most well-known artists are on display. It always amazes me to see how one building can be seen and interpreted by so many people in so many different ways.

You can make art out of anything. Some years ago I got the idea of giving each of the artists a white tie to decorate, and today we have a collection of over 300 hand-painted ties. You can't always take yourself seriously. Learning doesn't have to be dull. You can have fun making a lamp out of a used showerhead or making pepper mills out of the branches of dead trees.

When I was at McGill studying engineering physics, I had a teacher, Professor Watson, whose demonstrations of electromagnetism remain vivid in my memory. He had a metal tube wound with wire connected to an alternating current, and a rod went back and forth in a lewd manner. It was an effective yet simple way to demonstrate how polarity changes from north to south. 
Professor Watson led me to appreciate science and to read biographies of such prominent scientists as Richard Phillips Feynman and Niels Bohr. Feynman was not only an outstanding scientist who worked on the atomic bomb and expanded our understanding of quantum mechanics, but also a splendid raconteur and musician. Bohr won the Nobel Prize for Physics in 1922 for his contributions to our understanding of atomic structure. To me it is magnificent that people can think like they did. Learning about them has enriched my life.

Good teachers are passionate about what they do, and that passion comes through in their classrooms. Of all the teachers I had, the ones that I remember were interesting as people, sincerely interested in what they were doing, and interested in imparting something to their students. They weren't blasé. They didn't just read or comment on something but took a hands-on approach to education. I still remember Mr. Herbert at Baron Byng, who sang us arias from all kinds of operas. Thanks to his enthusiasm, Mr. Herbert left me with an appreciation of music. The only word that comes to mind, to describe all the teachers that had an influence on me, is "passionate." They imparted something more than information. They were caring educators who made a genuine effort to relate to their students.

Great minds DO NOT nor should they think alike. And, as I said previously: "If you are curious and receptive you can't help but learn."

\section{References}

Browning, R. (1855). Bishop Blougram's apology.

Victorian Poetry and Poetics. Boston:

Houghton Mifflin Company, 1968. 


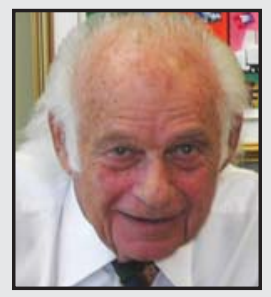

Avrum Morrow studied engineering physics at McGill University. In 1948 he founded Avmor-a manufacturer of professional cleaning chemicals - with Henry Chinks. Today, the company is an industry pioneer that employs some 100 people.

A passionate supporter of the arts, he transformed the company's original headquarters in Old Montreal into an art museum. Artists from all walks of life have been commissioned over the years to do paintings, photographs, drawings and sculptures of the Avmor building at 445 Ste Helene Street.

Morrow is a member of Concordia University's Fine Arts Advisory Board and also sits on the boards of the Montreal Heart Institute and the Montefiore Club. He received awards from the City of Montreal in both 1996 and 2000 as well as the Dobson Fellowship from McGill University in 2005. Morrow was named to the Order of Canada in 2007, making him the first person from the janitorial industry to receive such an honour. 